\title{
Comparison of mercury in atmospheric deposition and in Illinois and USA soils
}

\author{
E.C. Krug and D. Winstanley \\ Illinois State Water Survey, 2204 Griffith Drive, Champaign, IL, USA 61820 \\ Email for corresponding author: ekrug@sws.uiuc.edu
}

\begin{abstract}
It has been reported that most mercury (Hg) in USA soils is from atmospheric Hg deposition, mostly from anthropogenic sources. This paper compares the rates of atmospheric $\mathrm{Hg}$ deposition to amounts of $\mathrm{Hg}$ in Illinois and USA soils. The amounts of $\mathrm{Hg}$ in these soils are too great to be attributed mainly to anthropogenic atmospheric Hg deposition.
\end{abstract}

Keywords: mercury, atmospheric deposition, soil, geology, Illinois, USA

\section{Introduction}

The presumption that the amounts of mercury $(\mathrm{Hg})$ in the environment are naturally low and environmentally insignificant ( Borg et al., 1966; Harriss et al., 1970; Ackefors, 1971; Gardner, 1978; Johansson et al., 1991; U.S. Geological Survey, 2000) has influenced scientific and public perception about the amount and influence of human activities on $\mathrm{Hg}$ in the environment. The finding of widespread environmentally significant amounts of $\mathrm{Hg}$ in landscapes (even those far removed from human activities) leads to the conclusion that atmospheric deposition of anthropogenic $\mathrm{Hg}$ has increased $\mathrm{Hg}$ to environmentally significant levels (Travis and Hester, 1991; Lindqvist, 1991; U.S. Environmental Protection Agency, 1997; Wheatley and Wyzga, 1997; Iyengar and Nair, 2000; Pilgrim et al., 2000a,b; Lee et al., 2001; United Nations Environment Programme, 2002; Meili et al., 2003; Watanabe et al., 2003).

For the North American mid-continent, Swain et al. (1992), assuming no geological sources of $\mathrm{Hg}$ in the landscape and no mobilisation of $\mathrm{Hg}$ in aquatic sediments (Hg remains fixed in sediment at time of deposition), estimated that anthropogenic activities have increased atmospheric $\mathrm{Hg}$ deposition from a background deposition rate of $37 \mathrm{mg} \mathrm{ha}^{-1} \mathrm{yr}^{-1}$ in 1850 to $125 \mathrm{mg} \mathrm{ha}^{-1} \mathrm{yr}^{-1}$; most of this increase occurred after 1920. Meili (1995) reduced the background estimate to $20 \mathrm{mg} \mathrm{Hg} \mathrm{ha}^{-1} \mathrm{yr}^{-1}$ but subsequently, the U.S. Environmental Protection Agency (USEPA, 1997, p. 5-29) announced that the mean background atmospheric $\mathrm{Hg}$ deposition level for mid-continental North America may be even lower than Meili's revised estimate because $\mathrm{Hg}$ pollution of the atmosphere began before 1850. Also, $\mathrm{Hg}$ in Illinois and USA soils comes mainly from atmospheric deposition (USEPA, 1997, p. 5-33, 6-2; U.S. Geological Survey, 2000; Dreher et al., 2003b).

States in mid-continental North America have issued mercury advisories. For example, the Illinois Department of Public Health (2003), in its statewide advisory about high $\mathrm{Hg}$ levels in fish, states that $\mathrm{Hg}$ exists naturally in the environment in small amounts. The Wisconsin Department of Natural Resources (2001) considers Hg in the environment to be primarily of human origin. Although studies of $\mathrm{Hg}$ loading to rivers draining the upper Mississippi River drainage basin and other USA rivers show that the primary sources of $\mathrm{Hg}$ are from eroded soil and terrestrial plant materials, the unexamined assumption is that $\mathrm{Hg}$ associated with these materials is substantially anthropogenic (Balogh et al., 1998; 2003; Hurley et al., 1998). Mercury associated with sediments carried by the Mississippi River are reported to be primarily responsible for $\mathrm{Hg}$ fisheries advisories in the lower Mississippi River. 
For the USA, 520,000 river kilometres are reported to be under fish and wildlife advisories (Watanabe et al., 2003).

This paper briefly examines the hypothesis that $\mathrm{Hg}$ in Illinois and USA soils is predominantly of anthropogenic atmospheric origin.

\section{Methods}

The approach used to test the hypothesis about the anthropogenic source of soil $\mathrm{Hg}$ is to compare rates of atmospheric $\mathrm{Hg}$ deposition with soil and Earth crust $\mathrm{Hg}$ content, assuming soil retention of all deposited $\mathrm{Hg}$. The $\mathrm{Hg}$ content of Illinois soils (Table 1) was calculated using soil data sampled by the Illinois State Geological Survey (ISGS) at 51 soil sites in 45 counties covering the southern third of Illinois (Dreher et al., 2002, 2003a,b). These ISGS data are exceptional in that soils were sampled intensively in a relatively tight grid $(32 \mathrm{~km})$ at multiple depths throughout the soil profiles (Table 1). Topsoil was defined as the uppermost soil horizon sampled except for soil sites 12,18 , and 19 where topsoil soils depths of 24.4, 24.4, and $18.3 \mathrm{~cm}$ were used, respectively. Topsoil Hg content $\left(\mathrm{g} \mathrm{ha}^{-1}\right)$ was determined by multiplying the ISGS Hg concentration data by topsoil depth by topsoil bulk density (assumed to be $1.3 \mathrm{~g} \mathrm{~cm}^{-3}$ ). Total soil depth was defined as the depth of soil sampled except for soil site 29 where depth was assumed to be the top of the bottom-most layer sampled, $366 \mathrm{~cm}$. Total soil Hg content was determined by multiplying ISGS whole soil arithmetic mean $\mathrm{Hg}$ concentration values by total soil depth by bulk density, assumed to be $1.5 \mathrm{~g} \mathrm{~cm}^{-3}$ below the topsoil.

The Hg concentration of USA soils used is the average reported for the 1318 samples taken by the U.S. Geological Survey's $80-\mathrm{km}$ grid of the conterminous USA and sampled to a depth of about $20 \mathrm{~cm}$ (Shacklette and Boerngen, 1984). The quantity of $\mathrm{Hg}$ in average USA soil was calculated, assuming a soil depth of $20 \mathrm{~cm}$ and a bulk density of $1.3 \mathrm{~g} \mathrm{~cm}^{-3}$. Average world soil $\mathrm{Hg}$ concentration used was that reported by Andren and Nriagu (1979). Average soil content of $1,434 \mathrm{~g} \mathrm{Hg} \mathrm{ha}^{-1}$ was derived by dividing the total amount of $\mathrm{Hg}$ in the Earth's soil and, assuming that land area equals soil area, dividing this $\mathrm{Hg}$ value by the Earth's land area (Andren and Nriagu, 1979). Average soil depth used to derive the global average soil $\mathrm{Hg} \mathrm{ha}^{-1}$ value was estimated to be $140 \mathrm{~cm}$. This estimate was calculated by dividing global soil mass by global land area (Andren and Nriagu, 1979), assuming an average bulk density of $1.3 \mathrm{~g}$ $\mathrm{cm}^{-3}$ for the top $20 \mathrm{~cm}$ and $1.5 \mathrm{~g} \mathrm{~cm}^{-3}$ for the underlying soil.

Atmospheric $\mathrm{Hg}$ deposition for Illinois was defined as the sum of wet and dry $\mathrm{Hg}$ deposition. Wet $\mathrm{Hg}$ deposition is measured in Illinois by the U.S. Mercury Deposition Network (MDN). For the 1999-2001 period, MDN reports that the average annual measured wet $\mathrm{Hg}$ deposition in Illinois ranged from 90 to $96 \mathrm{ha}^{-1} \mathrm{yr}^{-1}$ with an average of $92 \mathrm{mg} \mathrm{ha}^{-1} \mathrm{yr}^{-1}$ (National Atmospheric Deposition Program, 2003). The USEPA (1997, p. 5-23) reports that dry $\mathrm{Hg}$ deposition in Illinois ranges from 10 to $100 \mathrm{mg} \mathrm{ha}^{-1} \mathrm{yr}^{-1}$. A total deposition value of $184 \mathrm{mg} \mathrm{Hg} \mathrm{ha} \mathrm{mgr}^{-1}$ for Illinois was derived by assuming that dry deposition equals wet deposition. Total average atmospheric deposition of $88.4 \mathrm{mg} \mathrm{Hg} \mathrm{ha} \mathrm{m}^{-1}$ for the conterminous USA was calculated from the USEPA estimate that an average total of 79.6 metric tons $\mathrm{Hg} \mathrm{yr}^{-1}$ is deposited on the conterminous USA (USEPA, 1997, p. 5-1). The Hg concentration and content of the Illinois soils (Table 1) were compared with data from the literature for USA soils, world soils and the Earth's crust. Average Hg contents in USA and the Illinois soils were compared to estimated natural background rates of atmospheric $\mathrm{Hg}$ deposition and average total annual $\mathrm{Hg}$ deposition rates for the USA and Illinois.

\section{Results and discussion}

On the global scale, $\mathrm{Hg}$ is a trace element: Mason and Moore (1982, pp. 42, 47) reported that the Earth's crust averages

Table 1. Concentration and content of mercury in southern Illinois soils.

\begin{tabular}{|c|c|c|c|c|c|c|}
\hline \multirow[t]{2}{*}{ Sample } & \multicolumn{3}{|c|}{$H g$ concentration $\left(\mu g \mathrm{~kg}^{-1}\right)$} & \multicolumn{3}{|c|}{ Soil depth $(\mathrm{cm})$} \\
\hline & median & mean & range & median & mean & range \\
\hline Topsoil & 28 & 34 & $18-104$ & 19.8 & 19.8 & $9.14-30.5$ \\
\hline \multirow[t]{2}{*}{ Whole soil } & 29 & 31 & $16-58$ & 381 & 380 & $181-579$ \\
\hline & \multicolumn{3}{|c|}{ Hg content $\left(g h a^{-1}\right)$} & & & \\
\hline Topsoil & 72 & 85 & $47-151$ & - & - & - \\
\hline Whole soil & 1630 & 1720 & $514-3980$ & - & - & - \\
\hline
\end{tabular}


but $80 \mu \mathrm{g} \mathrm{Hg} \mathrm{kg}^{-1}$. Shacklette and Boerngen (1984) reported that the average concentration of $\mathrm{Hg}$ in conterminous USA soils is $86 \mu \mathrm{g} \mathrm{kg}^{-1}$ (top $20 \mathrm{~cm}$ ) and Andren and Nriagu (1979) reported that the average concentration of $\mathrm{Hg}$ in world soils is $71 \mu \mathrm{g} \mathrm{kg}^{-1}$ (140 cm calculated soil depth).

The average concentration of $\mathrm{Hg}$ in the Illinois soils is even less than concentrations reported above for the Earth's crust, average USA soil and average world soil. The median and mean (average) concentrations of $\mathrm{Hg}$ for the topsoil $(\sim 20 \mathrm{~cm})$ from the Illinois soils are only 28 and $34 \mu \mathrm{g} \mathrm{kg}^{-1}$, respectively. Median and average topsoil $\mathrm{Hg}$ concentrations are not much different from those of the underlying $\sim 360$ $\mathrm{cm}$ of soil (Table 1). Nevertheless, the amount of $\mathrm{Hg}$ in these Illinois soils is large relative to atmospheric $\mathrm{Hg}$ deposition. Quantitatively, assuming that all atmospherically deposited $\mathrm{Hg}$ is retained in the top $\sim 20 \mathrm{~cm}$ of soil, the average amount of $\mathrm{Hg}$ in topsoil is equivalent to $\sim 400$ years of the current estimated rate of total $\mathrm{Hg}$ deposition (184 $\mathrm{mg} \mathrm{Hg} \mathrm{ha}^{-1} \mathrm{yr}^{-1}$ ) and equivalent to $\sim 4000$ years of a background level of total atmospheric $\mathrm{Hg}$ deposition value of $20 \mathrm{mg} \mathrm{Hg} \mathrm{ha}^{-1} \mathrm{yr}^{-1}$. Assuming that all atmospherically deposited $\mathrm{Hg}$ is retained in the $\sim 380 \mathrm{~cm}$-deep average whole soil profile, the average amount of $\mathrm{Hg}$ in whole soil is equivalent to $\sim 9000$ years of the current estimated rate of total atmospheric $\mathrm{Hg}$ deposition rate and equivalent to $\sim 90000$ years of the background rate of total atmospheric $\mathrm{Hg}$ deposition.

These quantities of $\mathrm{Hg}$ in the Illinois soils are too great to be attributed mainly to anthropogenic atmospheric $\mathrm{Hg}$ deposition.

The reported average $\mathrm{Hg}$ concentration of USA soils is about 2.5 times greater than that of the Illinois soils, whereas average USA total atmospheric $\mathrm{Hg}$ deposition is reported to be about half that of Illinois. Nevertheless, the USEPA (1997, p. 5-33, 6-2) concluded that most Hg in USA soils is anthropogenic by reporting that prior atmospheric anthropogenic $\mathrm{Hg}$ deposition USA soils contained only in the order of $10 \mu \mathrm{g} \mathrm{kg}^{-1}$. Assuming that all deposited $\mathrm{Hg}$ remains in the top $20 \mathrm{~cm}$ of soil, such an increase of $\mathrm{Hg}$ in the top $20 \mathrm{~cm}$ of average USA soil would require $\sim 2000$ years of total atmospheric $\mathrm{Hg}$ deposition at its current average USA rate of $88.4 \mathrm{mg} \mathrm{ha}^{-1}$ (USEPA, 1997, pp. 5-28 to 5-33). Assuming that the top $140 \mathrm{~cm}$ of USA soil now has the above reported world average soil, or the crustal $\mathrm{Hg}$ content and its natural $\mathrm{Hg}$ content was $10 \mu \mathrm{g} \mathrm{kg}^{-1}$, it would take $\sim 14000$ years or $\sim 16000$ years, respectively, for the current average estimated rate atmospheric $\mathrm{Hg}$ deposition to account for the $\mathrm{Hg}$ content of the soil if all deposited $\mathrm{Hg}$ remained in the soil.

These quantities of $\mathrm{Hg}$ in USA soils are too great to be attributed mainly to anthropogenic atmospheric $\mathrm{Hg}$ deposition.
When widespread $\mathrm{Hg}$ pollution first became a popular concern, global anthropogenic Hg was compared to global soil Hg (Wollast et al., 1975; Andren and Nriagu, 1979) as part of a larger literature that criticised the common presumption that the principle source of $\mathrm{Hg}$ in the environment is anthropogenic (e.g. Bertine and Goldberg, 1971; Goldwater, 1971; Hammond, 1971; Barber et al., 1972; Knauer and Martin, 1972; Miller et al., 1972; Goldberg, 1975; Ketchum et al., 1975). Regarding world soil $\mathrm{Hg}$ content, these early analyses reported that anthropogenic activities could have increased world soil $\mathrm{Hg}$ content by 0.02 percent (Wollast et al., 1975; Andren and Nriagu, 1979). Despite this early seminal literature and a persistent stream of similar publications in following decades (e.g. Varekamp and Buseck, 1981; Fitzgerald et al., 1984; Kabata-Pendias and Pendias, 1984, pp. 92, 116-125; Siegel and Siegel, 1984; Wolf and Peel, 1985; Morrison and Therein, 1991; Vandal et al., 1995; Roulet et al., 1998; 2000; Gustin et al., 2000; Lechler et al., 2000; Mason and Sheu, 2002; Gustin, 2003), the presumption that anthropogenic $\mathrm{Hg}$ is the principal source of $\mathrm{Hg}$ in the soils that mantle landscapes is still common and exerts a powerful effect on scientific and public perception of the role of anthropogenic atmospheric $\mathrm{Hg}$ deposition on the environment of Illinois and the USA.

\section{Conclusion}

The hypothesis that most $\mathrm{Hg}$ in Illinois and the USA soils is of anthropogenic origin is rejected. Whereas $\mathrm{Hg}$ is a trace element - its concentration is low compared to that of other Earth elements - Hg concentrations and contents of Illinois and USA soils are too great to be accounted for by atmospheric anthropogenic $\mathrm{Hg}$ deposition. This finding does not mean that atmospheric $\mathrm{Hg}$ pollution does not contribute to environmental $\mathrm{Hg}$. Nor does it mean that there are situations where conditions are such that most $\mathrm{Hg}$ does come from anthropogenic atmospheric deposition. It does indicate, however, that because environmentally significant amounts of natural $\mathrm{Hg}$ are generally found in soils, research is needed to investigate the mobility and fate of natural and anthropogenic $\mathrm{Hg}$ in terrestrial and aquatic environments.

\section{References}

Ackefors, H., 1971. Mercury pollution in Sweden with special reference to conditions in the water habitat. Proc. Roy. Soc. Lond. B, 177, 365-387.

Andren, A.W. and Nriagu, J.O., 1979. The global cycle of mercury. In: Topics in Environmental Health: Volume 3, The Biogeochemistry of Mercury in the Environment, J.O. Nriagu (Ed.). Elsevier/North-Holland Biomedical Press, Amsterdam, The Netherlands. 1-21. 
Balogh, S., Meyer, M. and Johnson, K., 1998. Diffuse and point source mercury inputs to the Mississippi, Minnesota, and St. Croix Rivers. Sci. Total Envir., 213, 109-113.

Balogh, S.J., Huang, Y., Offerman, H.J., Meyer, M.L. and Johnson D.K., 2003. Methylmercury in rivers draining cultivated watersheds. Sci. Total Envir., 304, 305-313.

Barber, R.T., Vijayakumar A. and Cross, F.A., 1972. Mercury concentrations in recent and ninety-year-old benthopelagic fish. Science, 178, 636-639.

Bertine, K.K. and Goldberg, E.D., 1971. Fossil fuel combustion and the major sedimentary cycle. Science, 173, 233-235.

Borg, K., Wanntorp, H., Erne, K. and Hanko, E., 1966 Mercury poisoning in Swedish wildlife. J. Appl. Ecol., 3, suppl., 171172.

Dreher, G.B., Follmer, L.R. and Zhang, Y., 2002. A progress report on the chemical composition of soils in Illinois: cores 1 through 10. Illinois State Geological Survey Open-File Series 2002-2, Champaign, IL, USA. 52pp.

Dreher, G.B., Follmer, L.R. and Zhang, Y., 2003b. A progress report on the description and chemical composition of soils in Illinois: cores 11 through 26. Illinois State Geological Survey OpenFile Series 2003-1, Champaign, IL, USA. 99pp.

Dreher, G.B., Follmer, L.R. and Zhang, Y., 2003a. A progress report on the description of the geology and chemical composition of soils in Illinois: cores 27 through 51. Illinois State Geological Survey Open-File Series 2003-3, Champaign, IL, USA. 128pp.

Fitzgerald, W.F., Gill, G.A. and Kim, J.P., 1984. An equatorial Pacific source of atmospheric mercury. Science 224, 597-599.

Gardner, D., 1978. Mercury in fish and waters of the Irish Sea and other United Kingdom fishing grounds. Nature, 272, 4951.

Goldberg, E.D., 1975. Man's role in the major sedimentary cycle. In: The Changing Global Environment, S.F. Singer (Ed.). D.Reidel Publishing, Dordrecht, The Netherlands. 275-294.

Goldwater, L.J., 1971. Mercury in the environment. Sci. Amer., 224(5), 15-21.

Gustin, M.S., 2003. Are mercury emissions from geologic sources significant? A status report. Sci. Total Envir., 304, 153-167.

Gustin, M.S., Lindberg, S.E., Austin, K., Coolbaugh, M., Vette, A. and Zhang, H., 2000. Assessing the contribution of natural sources to regional atmospheric mercury budgets. Sci. Total Envir., 259, 61-71.

Hammond, A.L., 1971. Mercury in the environment: natural and human factors. Science, 171, 788-789.

Harriss, R.C., White. D.B. and Mcfarlane, R.B., 1970. Mercury compounds reduce photosynthesis by plankton. Science, 170, 736-737.

Hurley, J.P., Cowell, S.E., Shafer, M.M. and Hughes, P.E., 1998. Tributary loading of mercury to Lake Michigan: importance of seasonal events and phase partitioning. Sci. Total Envir., 213, $129-137$.

Illinois Department of Public Health, 2003. Facts about Illinois' Methylmercury Advisory. Illinois Department of Public Health, Springfield, IL, USA. 3. Website: http://www.idph.state.il.us/ envhealth/fishadv/fishadvisory_qa.htm

Iyengar, G.V. and Nair, P.P., 2000. Global outlook on nutrition and the environment: meeting the challenges of the next millennium. Sci. Total Envir., 249, 331-346.

Johansson, K., Aastrup, M., Andersson, A., Bringmark, L. and Iverfeldt, A., 1991. Mercury in Swedish forest soils and waters - assessment of critical load. Water Air Soil Pollut., 56, 267-281.

Kabata-Pendias, A. and Pendias, H., 1984. Trace Elements in Soils and Plants. CRC Press, Boca Raton, FL, USA. 315pp.
Ketchum, B.H., Zitko, V. and Saward, D., 1975. Aspects of heavy metal and organohalogen pollution in aquatic ecosystems. In: Ecological Toxicology Research: Effects of Heavy Metals and Organohalogen Compounds: Proceedings of a NATO Science Committee Conference, A.D. McIntyre and C.F. Mills (Eds.). Plenum Press, New York, USA. 75-90.

Knauer, G.A. and Martin, J.H., 1972. Mercury in a marine pelagic food chain. Limnol. Oceanogr., 17, 868-876.

Lechler, P.J., Miller, J.R., Lacerda, L.D., Vinson, D., Bonzongo, J.C., Lyons, W.B. and Warwick, J.J., 2000. Elevated mercury concentrations in soils, sediments, water, and fish of the Madeira River basin, Brazilian Amazon: a function of natural enrichments? Sci. Total Envir., 260, 87-96.

Lee, D.S., Fowler, D. and Nemitz, E., 2001. New directions: the European Air Quality Framework Directive and atmospheric mercury: the wrong tool for the job? Atmos. Environ., 35, 58555857

Lindqvist, O. (Ed.), 1991. Mercury as an environmental pollutant: refereed papers from the international conference held in Gavle, Sweden, June 11-13, 1990. Water Air Soil Pollut., 56, 1-847.

Mason, B. and Moore, C.B., 1982. Principles of Geochemistry. Fourth Edition. Wiley, New York, USA. 344pp.

Mason, R.P. and Sheu, G.R., 2002. Role of the ocean in the global mercury cycle. Global Biogeochem. Cycles 16, 40-1-40-14.

Meili, M., 1995. Preindustrial atmospheric deposition of mercury - uncertainty rates from lake sediment and peat cores. Water Air Soil Pollut., 80, 637-640.

Meili, M., Bishop, K., Bringmark, L., Johansson, K., Munthe, J., Sverdrup, H. and de Vries, W., 2003. Critical levels of atmospheric pollution: criteria and concepts for operational modelling of mercury in forest and lake ecosystems. Sci. Total Envir., 304, 83-106.

Miller, G.E., Grant, P.M., Kishore, R., Steinkruger, F.J., Rowland, F.S. and Guinn, V.P., 1972. Mercury concentrations in museum specimens of tuna and swordfish. Science, 175, 1121-1122.

Morrison, K.A. and Therien, N., 1991. Experimental evaluation of mercury release from flooded vegetation and soils. Water Air Soil Pollut., 56, 607-619.

National Atmospheric Deposition Program, 2003. Mercury Deposition Network, Illinois State Water Survey, Champaign, IL, USA. Website: http://nadp.sws.uiuc.edu/mdn/maps/

Pilgrim, W., Poissant, L. and Trip, L., 2000a. The Northeast States and Eastern Canadian Provinces mercury study: a framework for action: summary of the Canadian chapter. Sci. Total Envir., 261, 177-184

Pilgrim, W., Schroeder, W., Porcella, D.B., Santos-Burgoa, C., Montgomery, S., Hamilton, A. and Trip, L., 2000b. Developing consensus: mercury science and policy in the NAFTA countries (Canada, the United States and Mexico). Sci. Total Envir., 261, 185-193.

Roulet, M., Lucotte, M., Saint-Aubin, A., Tran, S., Rheault, I., Farella, N., De Jesus Da Silva, E., Dezencourt, J., Passos, C.J.S., Soares, G.S., Guimaraes, J.R.D., Mergler, D. and Amorim, M., 1998. The geochemistry of mercury in central Amazonian soils developed on the Alter-do-Chao formation of the lower Tapajos River Valley, Para state, Brazil. Sci. Total Envir., 223, 1-24.

Roulet, M., Lucotte, M., Canuel, R., Farella, N., Courcelles, M., Guimaraes, J.R.D., Mergler, D. and Amorim, M., 2000. Increase in mercury contamination recorded in lacustrine sediments following deforestration in the central Amazon. Chem. Geol., 165, 243-266.

Shacklette, H.T. and Boerngen, J.G., 1984. Element concentrations in soils and other surficial materials of the conterminous United States. U.S. Geological Survey Professional Paper 1270. U.S. Geological Survey, Alexandria, VA, USA. 105pp. 
Siegel, S.M. and Sieleg, B.Z., 1984. First estimate of annual mercury flux at the Kilauea main vent. Nature, 309, 146-147.

Swain, E.B., Engstrom, D.R., Brigham, M.E,, Henning, T.A. and Brezonik, P.L., 1992. Increasing rates of atmospheric deposition in midcontinental North America. Science, 257, 784-787.

Travis, C.C. and Hester, S.T., 1991. Global chemical pollution. Environ. Sci. Technol., 25, 814-819.

United Nations Environment Programme, 2002. Global Mercury Assessment. UNEP Chemicals, Geneva, Switzerland. 258pp.

U.S. Environmental Protection Agency, 1997. Mercury Study Report to Congress. Volume III: Fate and Transport of Mercury in the Environment. EPA-452/R-97-005. U.S. Environmental Protection Agency, Washington, DC, USA. various paging.

U.S. Geological Survey, 2000. Mercury in the Environment. U.S. Geological Survey Fact Sheet 146-00. U.S. Geological Survey, Reston, VA, USA. 6pp.

Vandal, G.M., Fitzgerald, W.F., Boutron, C.F. and Candelone, J.P., 1995. Mercury in ancient ice and snow from the Antarctic. In: Ice Core Studies of Global Biogeochemical Cycles: Proc. of the NATO Advanced Research Workshop "Ice Score Studies of Global Biogeochemical Cycles," held in Annecy, France, March 26-31, 1993, R.J. Delmas (Ed.). Springer, Berlin, Germany. 401415 .
Varekamp, J.C. and Buseck, P.R., 1981. Mercury emissions from Mount St Helens during September 1980. Nature, 293, 555556.

Watanabe, K.H., Desimone, F.W., Thiyagarajah, A., Hartley, W.R. and Hindrichs, A.E., 2003. Fish tissue quality in the lower Mississippi River and health risks from fish consumption. Sci. Total Envir., 302, 109-126.

Wheatley, B. and Wyzga, R. (Eds.), 1997. Mercury as a global pollutant: human health issues, fourth international conference on mercury as a global pollutant, Hamburg, Germany, 4-8 August 1996. Water Air Soil Pollut., 97, 1-198.

Wisconsin Department of Natural Resources, 2001. Controlling mercury a top priority at the DNR. DNR News, April 24, 2001. 11-14. Website: http://www.dnr.state.wi.us/org/caer/ce/news/on/ 2001/ON010424.htm

Wolff, E.W. and Peel, D.A., 1985. The record of global pollution in polar snow and ice. Nature, 313, 535-540.

Wollast, R., Billen, G. and MacKenzie, F.T., 1975. Behavior of mercury in natural systems and its global cycle. In: Ecological Toxicology Research: Effects of Heavy Metals and Organohalogen Compounds: Proceedings of a NATO Science Committee Conference, A.D. McIntyre and C.F. Mills (Eds.). Plenum Press, New York, USA. 145-166. 